\title{
Presence of Radionuclide Concentrations in Himalayan Region of Uttarakhand, India-
}

\section{A Review}

\author{
Taufiq Ahamad $^{1 *}$ O P Nautiyal ${ }^{2} \cdot$ Rohit Singh Sajwan $^{3} \cdot$ A A Bourai ${ }^{4}$ A S Rana ${ }^{1}$ Prakhar \\ Singh $^{2} \cdot$ Manoj Baluni $^{1} \cdot S$ C Nautiyal ${ }^{5}$ \\ ${ }^{1}$ Department of Physics, Shri Guru Ram Rai PG College, Dehradun 248001, India \\ ${ }^{2}$ Uttarakhand Science Education and Research Centre, Dehradun 248001, India \\ ${ }^{3}$ Department of Chemistry, HNB Garhwal University, Badshahi Thaul Campus, Tehri Garhwal 249199, India \\ ${ }^{4}$ Department of Physics, HNB Garhwal University, Badshahi Thaul Campus, Tehri Garhwal 249199, India \\ ${ }^{5}$ Deptt. of Physics, Govt.PG College Maldevta, Raipur, Dehradun,India
}

*Corresponding Author E-mail: taufiqahamad1507@gmail.com

Received: 29.8.2021; Revised: 25.11.2021; Accepted: 27.11.2021

(O) Society for Himalayan Action Research and Development

\begin{abstract}
Earth is a major source of several elements which are occurring with different physical and chemical properties in nature. Some of the elements are categorized as Naturally Occurring Radioactive Materials and termed as NORMs. These natural sources and anthropogenic sources combined make the earth's environment radioactive and human beings continuously receive the amount of the total radiation dose more than $50 \%$ of the radiation that comes from radon and thoron. It has been evident that soil is the furthermost important feature that affects the radon/thoron level in the human living surroundings which increases human exposure to radioactivity. The concentration of natural radionuclides elements present in soil or rocks is the main feature of levels of natural background radiation dose. This review paper represents the activity level of Ra-226, Th-232, and K-40 in soil samples of the Himalayas region of Uttarakhand. The data so obtained from previous studies of radionuclides shows the high abundance of radioactive mineralization in the soil of the Himalayan region in the Uttarakhand state of India.
\end{abstract}

Keywords: Soil, Radionuclides, Ra-226, Th-232 and K-40, Gamma Ray Spectroscope

\section{Introduction}

Earth is made up of a variety of elements, each with its own set of physical and chemical properties, and some of them are radioactive elements (Krebs, 2006; Yadav et al., 2015). The earth's atmosphere is radioactive due to natural and human-made causes (Al-Khawlany et al., 2018). The toxicity due to radioactivity is a very natural occurrence all over the world for the Human. Important causes of radiation exposure include the presence of radon ( $\mathrm{Rn}$ 222) and thoron (Rn-220) in the human atmosphere (Kaur et al., 2019). Radiation from radon and thoron accounts for more than half $(50 \%)$ of the overall exposure received from humans and up to $70 \%$ of the global contamination caused by natural sources of radiation that contributes to substantial radiological research in order to estimate the effect on living being (UNSCEAR, 2000).

Rn-222 and Rn-220 are noble radioactive gases and are found as a daughter radioactive element of the U-238 and Th-232 decay sequence, which disintegrates into the stable product like $\mathrm{Pb}-206$ and $\mathrm{Pb}-208$, respectively, and are abundantly present in rocks/soil (Alnour et al., 2012) Fig.1 (a) and (b). The energy of alpha particles emitted during the disintegration of the U-238 and Th-232 is harmful to the human tissue and caused health 
issues (Ahamad et al., 2021). The primary source of radon and thoron exhalation into the atmosphere also radio-nuclides found in soil or rocks (Semwal et al., 2018).

The main causes of human exposure to radioactive compounds are radon, thoron, and their progeny. Ra-226, Th-232, and K-40 are naturally occurring radionuclides found in soil

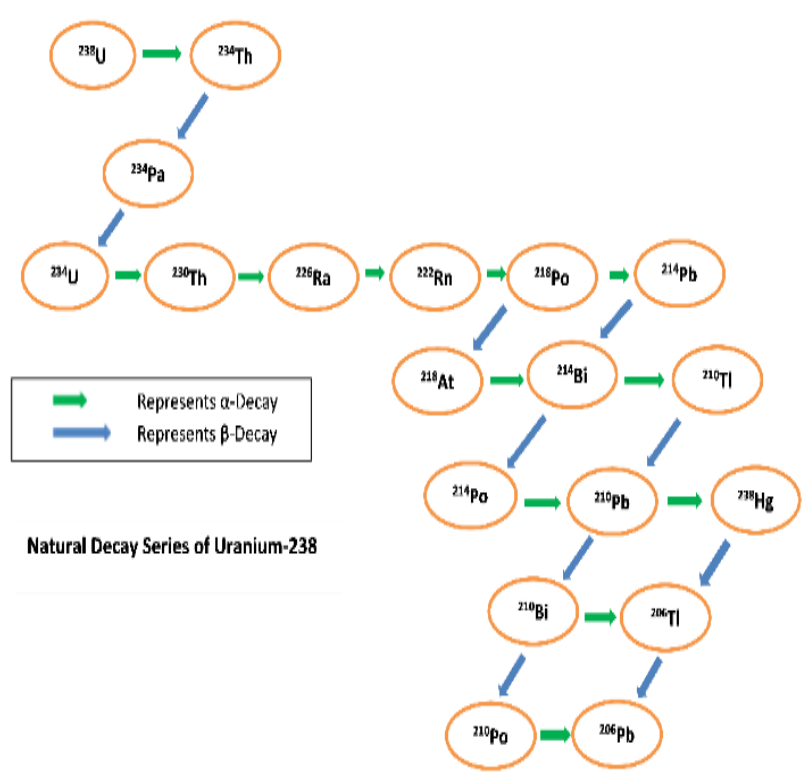

(a) Decay series of Uranium and rocks (Ramola et al., 2008). It has been observed that a high exhalation rate is obtained in those soil samples which have a high amount of Ra-226 activity (Yadav et al., 2016). Indoor radon, thoron concentration has a significant correlation with the activity concentration of radionuclides (Kumar et al., 2021).

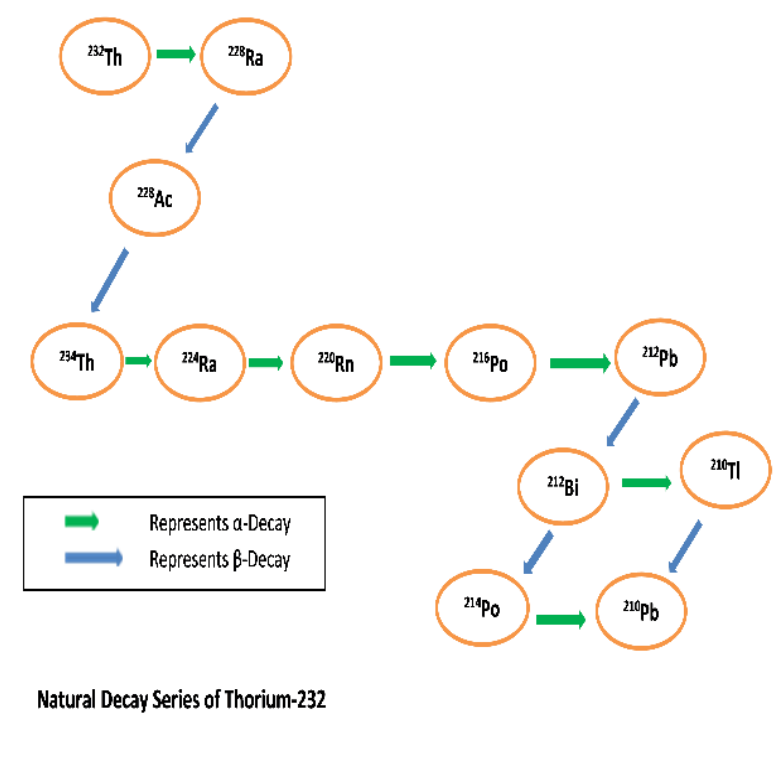

(b) Decay series of Thorium

Fig. 1: Decay series and daughter product of (a) Uranium and (b) Thorium

The World Health Organization has recommended the reference limit which is get reduced from $200 \mathrm{~Bq} / \mathrm{m} 3$ to $100 \mathrm{~Bq} / \mathrm{m} 3$ and has identified radon as the second most carcinogenic gas for humans after smoking (WHO, 2009). The majority of the radiation doses are determined by the concentration of these radionuclides in the earth's crust. Radionuclides are helpful for the estimation of Radiological Health Hazard Index $\left(\mathrm{H}_{\mathrm{ex}}=\right.$ external and $\mathrm{H}_{\text {in }}=$ internal health effects), Radium Equivalent Activity ( $\left(\mathrm{Ra}_{\mathrm{eq}}\right)$, Absorbed dose (D), Annual effective dose (for Indoor and Outdoor), and Gamma Activity Index $\left(\mathrm{I}_{\gamma}\right)$ (Ramola et al., 2008).

The present study represents a review of the presence of Radionuclide concentrations in the Himalayan Region of Uttarakhand, India based on the past studies done in various parts 
of the Uttarakhand state, India which gives strong evidence for the presence of radioactive mineralization across the state.

\section{Environmental Radioactivity in ambient} Air

Environmental radioactivity is termed as natural radioactivity in the ambient air which increases by the natural background radiation by radon (Rn-222 and Rn-220) and gamma exposure. Terrestrial background radiation, or gamma radiation released from NORMs (Naturally-Occurring Radioactive Materials), is a major indirect cause of human body radiation exposure. Natural ambient radioactivity and the resulting external gamma radiation emission are largely determined by geological and geographical factors. Soil contains radioactive elements such as plutonium, thorium, and potassium along with organic and inorganic compounds (Ramola et al., 2008). U-234, U-235, U-238, Ra-226, Th232 etc., natural radionuclide distribution is not constant, and external radiation exposure varies by a factor. Natural radiation is the most significant contributor to the global population's total exposure (UNSCEAR, 2000). Radon and its isotopes are transferred to indoor air via. dwellings include windows and doors, as well as construction materials used in the walls, floors, and ceilings, which increase the natural background radiation exposure. It is being researched in a number of countries and it was also named as the second leading cause of lung cancer, after smoking
(Kreienbrock et al., 2001; Letoureau et al., 1994; Jonsson et al., 1988; Kandari et al., 2016).

More than half $(50 \%)$ of the ionizing radiation received by humans comes from radon, thoron, and their daughter products, when inhaled (UNSCEAR, 2000). The doses received as a result of radon and thoron were primarily contributed by their daughter products, according to a subsequent study (UNSCEAR, 2008). Therefore, it is essential to measure their daughter products (Ramola et al., 2016; Ramola et al., 2014; Prasad et al., 2016; Bangotra et al., 2015).

\section{Geology of Uttarakhand}

The present study is based on previous studies conducted in Uttarakhand state of Himalaya region, which is located at the northern part of India on the foothills of the Himalayan mountain range, located on $29-30^{\circ} \mathrm{N}$ latitude and $78-79^{\circ}$ E longitude with Himalayan peaks (second highest peak Nanda Devi peak with $7681 \mathrm{~m}$ altitude) and glaciers and it has a total covered area of the state is $53,483 \mathrm{~km}^{2}$ with $86 \%$ mountain. The significant value of the activity of radionuclides was recently reported in Uttarakhand and hence, the present study is based on the data of radionuclides distribution over the state. Generally, Uttarakhand is covered by hilly forest (65\% total forest) with a population of 10.08 million as per 2011 senses. Garhwal and Kumaun divisions are the two main divisions of the state (wikipedia/Geology of Uttarakhand). Minerals 
and ores abound in the province. Mylonitized porphyritic, lime, granite, quartz porphyry, phyllites, quartzite, schist, slates, and a wide variety of sedimentary rocks are found in the state. The final and stable state of radioactive elements is lead $(\mathrm{Pb})$ (Valdiya et al., 1980; Ramola et al., 2006). The state of Uttarakhand has a high concentration of $\mathrm{Pb}$ in its various districts like Dehradun, Chamoli, Pauri, etc. Uttarakhand's lithotectonic units like the main central thrust (MCT) area are prone to a significant number of tectonic events per year with lesser Himalayan zone, the main boundary thrust (MBT) separates tertiary and pre-tertiary rocks and involves sediment portion (Bilham, 2004; Ansari, 2018). A significant activity of radionuclides has been estimated in MCT and MBT regions of Uttarakhand Himalayan region, India earlier (Ramola et al., 2014; Kandari et al., 2018).

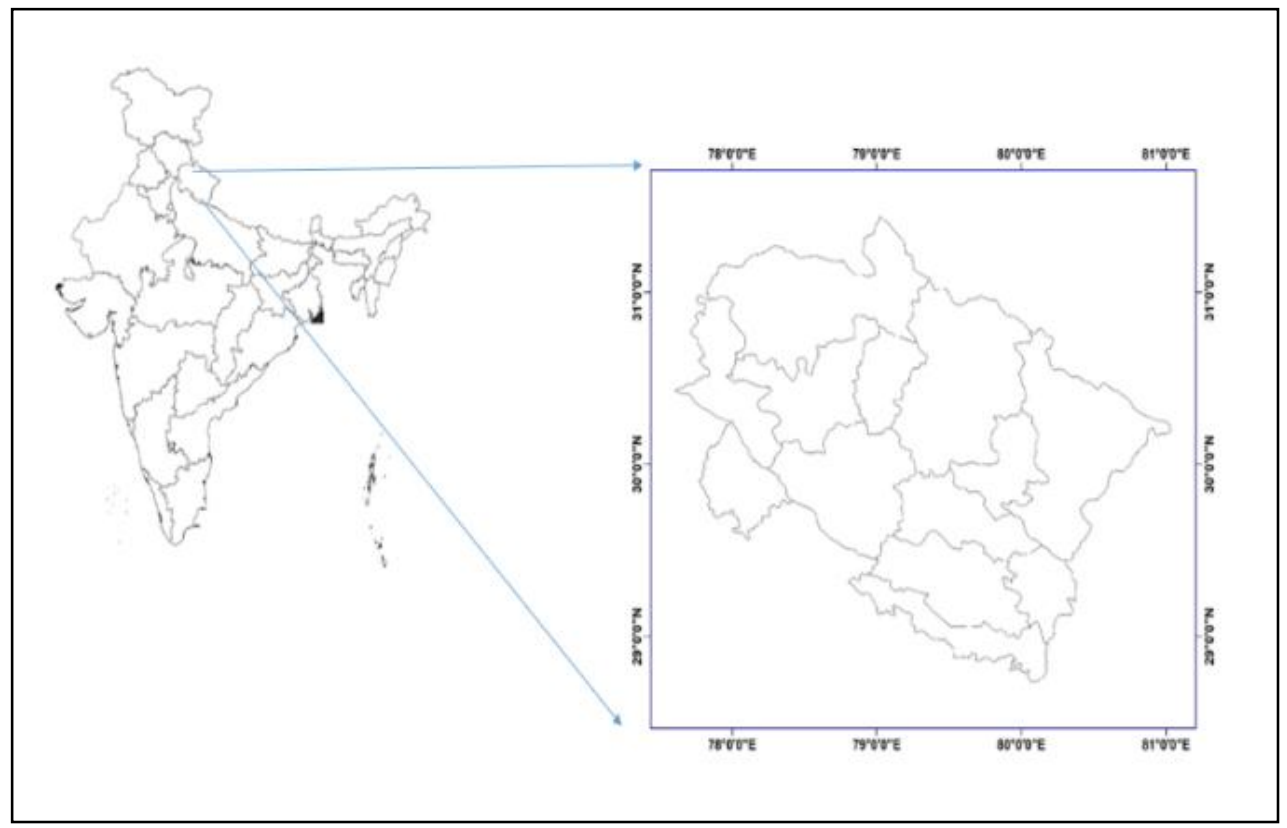

Fig. 2: Map of Uttarakhand

\section{Materials and Methodology}

\section{Collection and preparation of Soil samples}

\section{for analysis}

During the soil sample's collection across the different parts of the study area, other entities such as pebbles, small rocks, roots, and leaves are removed from the soil, which is then packed in airtight packaging before analysis starts. Radon is transported into the air from the soil profile mainly by the emanation and exhalation process.
After soil sampling, a mesh with a mesh size of 150 microns was used to dry and prepare the samples. The soil samples were then sealed by using the airtight container for avoiding moisture and placed for a month to attain secular equilibrium between Ra-226, Rn-222, and their daughter products present in the soil. Scintillation $\mathrm{NaI}$ ( $\mathrm{Tl}$ ) gamma radiation detector (gamma-ray spectrometry) of scale 63 $\mathrm{mm} \times 63 \mathrm{~mm}$ with several channel analyzers are used to measure radionuclides in soil 
samples for 3 hours of counting time to have the values of radionuclide activity in soil (Rautela et al., 2012).

\section{Radionuclide Measurement (Mehra et al., 2007)}

Gamma-ray spectrometry is a combined twodetector spectrometric and radiometric instrument to measure mixed gamma beta radiation. The device was designed to identify and quantify gamma-emitting isotopes in a number of soil matrices. It can detect multiple Gamma emitting radionuclides in a single sample with minimal sample preparation. The calculation yields a continuum of lines, whose amplitude is proportional to the radionuclide's operation and whose location on the horizontal axis indicates its emitted energy. The spectrometer detects gamma radiation in the energy range from 50 to $3000 \mathrm{keV}$ and beta radiation in the range of boundary from 150 to $3500 \mathrm{keV}$. It can measure gamma and beta radiation simultaneously. The spectrometer provides stabilization of the energy range on the energy line of $661.6 \mathrm{keV}$ from the reference source Cs-137, $9 \mathrm{kBq}$, and also its operability and calibration safety controls with this reference source. The unit of Gamma detection is made up of a scintillation detector $\mathrm{NaI}$ (TI) with a scale of $63 \times 63 \mathrm{~mm}$, as well as electronic components such as a photomultiplier, amplification unit, selector, and light-emitting diode (Reguigui, 2006).
For sample preparation, the soil was dried in an oven at a temperature of $100^{\circ} \mathrm{C}$ to $120^{\circ} \mathrm{C}$, and the sample size should be 150 microns. $250 \mathrm{~g}$ of dried soil was packed in an airtight Marinelli vessel and for four weeks, the radionuclide and its daughter products were held in a state of secular equilibrium with each other. The acquire peak of Gamma spectra was normalized by comparing it to the $661 \mathrm{keV}$ peak of Cs-137. The central component of gamma spectroscopy is the detector. In the case of annihilation, the gamma photons interfere with the detector substance and pass their energies to electrons or positrons. Ionized atoms and ion pairs are formed as these created particles lose their energy inside the detector. The detector signal is made up of these alternative entities (Reguigui, 2006).

A photomultiplier tube converts a light pulse generated by a gamma-ray communicating with a scintillator into an electric pulse. A photomultiplier is made up of a photocathode, electrode used for focusing, and dynodes (10 or more), each of which multiplies the number of electrons striking it several times. Transparency, large size availability, and large light intensity relative to gamma-ray energy are all properties of scintillation material that are needed for good detectors and very few materials have strong detector properties. NaI and CsI crystals that have been activated with thorium are widely used. The high $\mathrm{Z}$ of iodine in $\mathrm{NaI}$ provides good gamma-ray detection ability. To unlock the crystal, a slight amount of $\mathrm{Tl}$ is added, so the crystal is normally 
referred to as $\mathrm{NaI}$ (Tl). For the $662 \mathrm{keV}$ gamma-ray from Cs-137, the highest resolution achieved varies from 7.5 percent to 8.5 percent for a 3 in. diameter by 3 in. long crystal, which is significantly weaker for smaller and larger sizes. To massive crystals with several phototubes for X-ray measurements with a comparatively thin detector (to maximize resolution at the cost of performance at higher energies). A common configuration is crystals used with a well to allow virtually spherical 4P geometry for counting filler samples. Because of its good gamma-ray resolution and low cost, $\mathrm{NaI}$ is still the most used material for gamma detection. Commercially affordable NaI detector configurations are available. The detailed work can be found elsewhere (Reguigui, 2006).

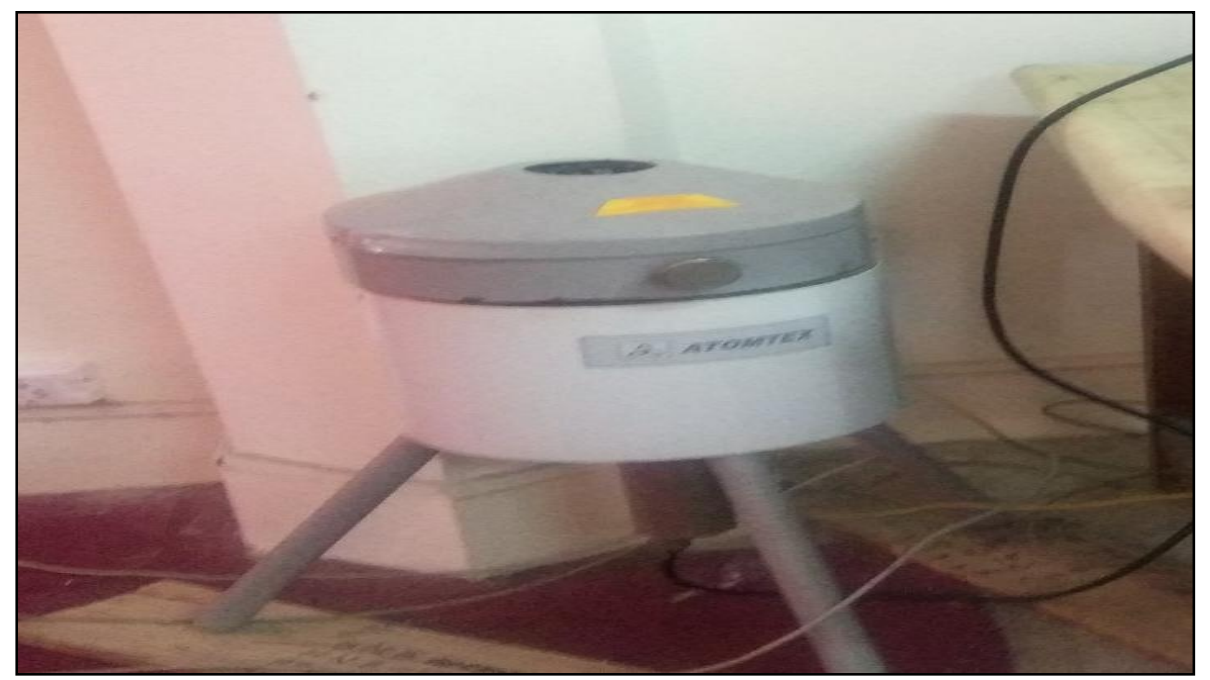

Fig. 3: Gamma Spectroscopy

\section{Radium equivalent activity}

The following formula (eq. 1) is used for the calculation of radium equivalent activity which gives radionuclide concentration used to define radiation hazard associated with Ra226, Th-232, and K-40 (UNSCEAR, 2000; Ramola et al., 2008).

$\mathrm{Ra}_{\mathrm{eq} .}=\mathrm{A}_{\mathrm{Ra}}+1.43 . \mathrm{A}_{\mathrm{Th}}+0.77 . \mathrm{A}_{\mathrm{K}}$

Where $\mathrm{A}_{\mathrm{Ra}}=$ Activity concentration of Ra226, $\mathrm{A}_{\mathrm{Th}}=$ Activity concentration of Th-232, $\mathrm{A}_{\mathrm{K}}=$ Activity concentration of $\mathrm{K}-40$.

\section{Absorbed Gamma Dose rate}

As per the UNSCEAR, 2000 the absorbed dose rate due to natural radio-nuclide is calculated using the by using conversion factor (eq. 2)

$\mathrm{D}=0.604 \mathrm{~A}_{\mathrm{Th}}+0.463 \mathrm{~A}_{\mathrm{Ra}}+0.0417 \mathrm{~A}_{\mathrm{K}}$

Here $A_{R a}=$ Avg. Activity concentration of Ra-226, $A_{T h}=$ Avg. Activity concentration of Th-232, $A_{K}=$ Avg. Activity concentration of K-40. 


\section{Results and Discussion}

The measured activity concentration of Radium, Thorium, and Potassium in different areas of Himalayan regions are found from 50 to $285 \mathrm{~Bq} / \mathrm{Kg}, 38$ to $384 \mathrm{~Bq} / \mathrm{Kg}$, and 310 to $2126 \mathrm{~Bq} / \mathrm{Kg}$ with an average value of 112.78 , 126.46, and $1210.51 \mathrm{~Bq} / \mathrm{Kg}$ respectively. The details of radionuclide activity of a variable region of Himalaya Uttarakhand are shown in table 1. The activity concentration of radionuclides radium, thorium, and potassium is much higher in comparison to the world average value of 35,30 , and $400 \mathrm{~Bq} / \mathrm{kg}$ according to UNSCEAR 2000 report. The highest Radium concentration was found in the Uttarkashi area while the lowest value was found in the Ukhimath area highest value may be due to the presence of a thrust plane and Uttarkashi is a highly uranium mineralized area (Bist et al., 1999; Ramola et al., 1988).

Table 1. Ra, Th, K-40, Absorbed Gamma Dose Rate, and Average Raeq.

\begin{tabular}{|c|c|c|c|c|c|c|}
\hline $\begin{array}{l}\text { Study } \\
\text { Area }\end{array}$ & $\begin{array}{l}\text { Ra-226 } \\
(\mathrm{Bq} / \mathrm{kg})\end{array}$ & $\begin{array}{l}\text { Th-232 } \\
(\mathrm{Bq} / \mathrm{kg})\end{array}$ & $\begin{array}{l}\mathrm{K}-40 \\
(\mathrm{~Bq} / \mathrm{kg})\end{array}$ & $\begin{array}{c}\text { External Absorbed } \\
\text { Gamma Dose Raten } \\
(\mathrm{nGy} / \mathrm{h})\end{array}$ & $\begin{array}{l}\text { Average } \\
\text { Radium } \\
\text { Equivalent } \\
(\mathrm{Bq} / \mathrm{kg})\end{array}$ & Reference \\
\hline $\mathrm{S} 1$ & $131 \pm 18$ & $384 \pm 53$ & $1406 \pm 175$ & 306 & 300 & $\begin{array}{l}\text { (Ramola et al., } \\
\text { 2008) }\end{array}$ \\
\hline $\mathrm{S} 2$ & $\begin{array}{l}166.6 \pm 12 . \\
9\end{array}$ & $94.7 \pm 9.7$ & $1378 \pm 37$ & 179.6 & 384.2 & $\begin{array}{l}\text { (Gusain et al., } \\
\text { 2009) }\end{array}$ \\
\hline S3 & $\begin{array}{l}141.7+11 \\
9\end{array}$ & $\begin{array}{l}155.9+12 . \\
4\end{array}$ & $672.8+25.9$ & 169.1 & 276.9 & $\begin{array}{l}\text { (Rautela et al., } \\
\text { 2012) }\end{array}$ \\
\hline S4 & $50 \pm 10$ & $88 \pm 16$ & $885 \pm 132$ & 113 & 86 & $\begin{array}{l}\text { (Yadav et al., } \\
2014)\end{array}$ \\
\hline S5 & $\begin{array}{l}79.6 \quad \pm \\
18.4\end{array}$ & $99 \pm 8.8$ & $\begin{array}{l}1201.3 \quad \pm \\
418.3\end{array}$ & 144 & 266.8 & $\begin{array}{l}\text { (Kandari et al., } \\
2018)\end{array}$ \\
\hline S6 & $285 \pm 28$ & $136 \pm 15$ & $1588 \pm 185$ & 188 & 176.6 & $\begin{array}{l}\text { (Ramola et al., } \\
\text { 2014) }\end{array}$ \\
\hline S7 & $55 \pm 10$ & $101 \pm 13$ & $1310 \pm 154$ & 93 & 221 & $\begin{array}{l}\text { (Yadav et al., } \\
2015)\end{array}$ \\
\hline S8 & $73 \pm 12$ & $99 \pm 14$ & $2126 \pm 176$ & 148 & 228 & $\begin{array}{l}\text { (Kumar et al., } \\
2021)\end{array}$ \\
\hline S9 & $\begin{array}{l}69.85 \quad \pm \\
9.77\end{array}$ & $38 \pm 7.37$ & $1991 \pm 256$ & - & - & $\begin{array}{l}\text { (Semwal et al., } \\
\text { 2018) }\end{array}$ \\
\hline $\mathrm{S} 10$ & $76 \pm 11$ & $69 \pm 10$ & $549 \pm 67$ & 96 & 174 & $\begin{array}{l}\text { (Anamika et al., } \\
\text { 2020) }\end{array}$ \\
\hline
\end{tabular}


represents highly thorium mineralization. The maximum Potassium activity was found in Bageshwer and the minimum value was found in Shestradhara, Dehradun the high value was due to the usage of potassium-rich fertilizers. The overall data shows that the concentration of naturally occurring radionuclides directly is subject to the geological and geophysical features of the area (Bist et al., 1999). The distribution of radionuclide is shown in graph Fig. 4.

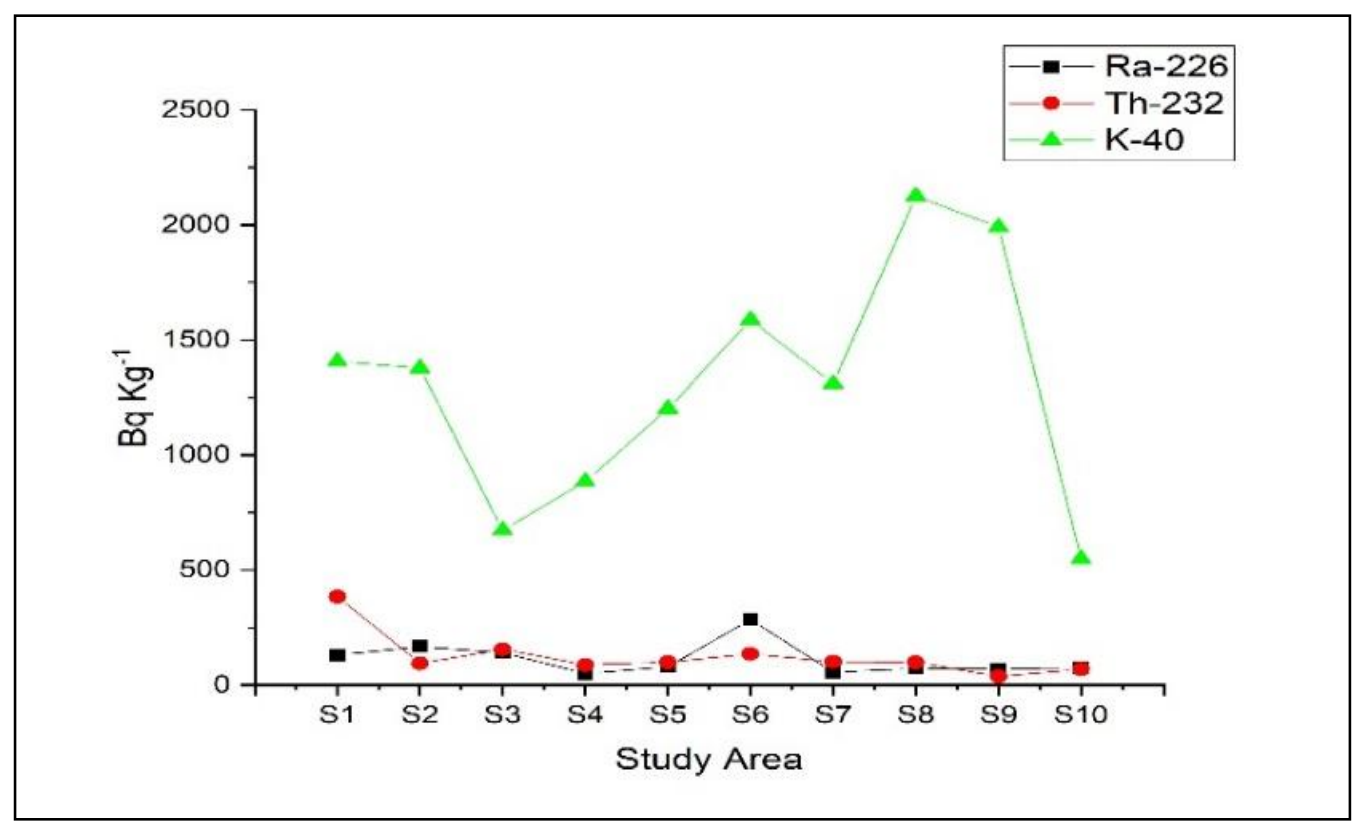

Fig. 4: Distribution graphs Ra, Th, K-40 radionuclides

The distribution of radionuclide is not even hence exposure due to radionuclides is measured in terms of average radium equivalent activity. The average Radium equivalent in the area is shown in table 1 and range varies from 86 to $384.20 \mathrm{~Bq} / \mathrm{Kg}$ with an average value of 234.84

$\mathrm{Bq} / \mathrm{Kg}$. The average value of radium equivalent was lower than recommendation level $370 \mathrm{~Bq} / \mathrm{Kg}$ and acceptable for use (OECD, 1979). Approx $44.4 \%$ of radium equivalent found near $250 \mathrm{~Bq} / \mathrm{Kg}$ Fig. 6(b).

External absorbed Gamma Dose rate was also calculated from soil samples and gamma dose rate varies from 93 to $306 \mathrm{nGy} / \mathrm{h}$ [with an average value of $159.63 \mathrm{nGy} / \mathrm{h}$ which is greater than the global average value of 57 nGy/h (Ramola et al., 2016; UNSCEAR, 2008). The frequency distribution of external absorbed Gamma Dose rate shown in fig. 5 (a). Box plots of data are shown in Fig. 6. Table 2 represents the statistical data representation of study locations mentioning Max., Min., Average and Std. Deviation.

\section{Conclusion}

The study displays that the total activity concentration of Ra-226, Th-232, and K-40 in different areas of the Himalayas is higher than the reference level given by the UNSCEAR 2000. The average radium equivalent activity was found below the recommended level while the external absorbed gamma dose rate 
was found above the reference. The Uttarakhand has associated with highly seismic areas and comes under IV and $\mathrm{V}$ seismic zone and most of the locations are situated along with the MCT, MBT, and MFT and holds various types of geology. The state consists most tectonically active zone from a geophysical point of view. Because of tectonic activity in the Himalayan region, there may be a huge change in the radionuclide concentration. The higher value of radionuclide is may be due to the geochemical composition of the soil and geophysical conditions. As all these radionuclide elements are not uniformly distributed in soil and rocks will play a significant role in the measurement of Radon transportation and help to find health Hazard due to indoor radon-thoron concentration.

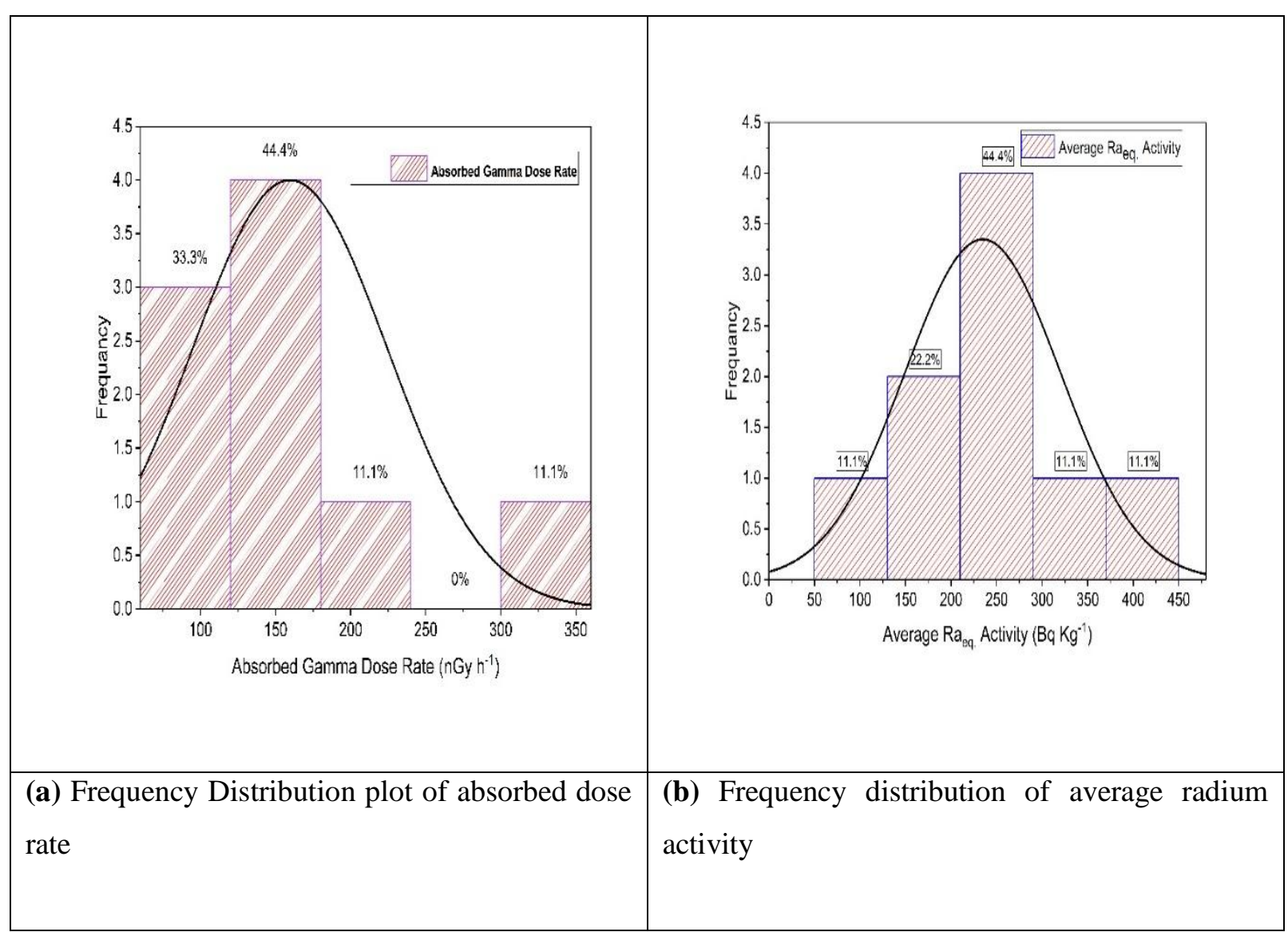

Fig. 5: Frequency Distribution plot of (a )absorbed dose rate and (b) average radium activity 


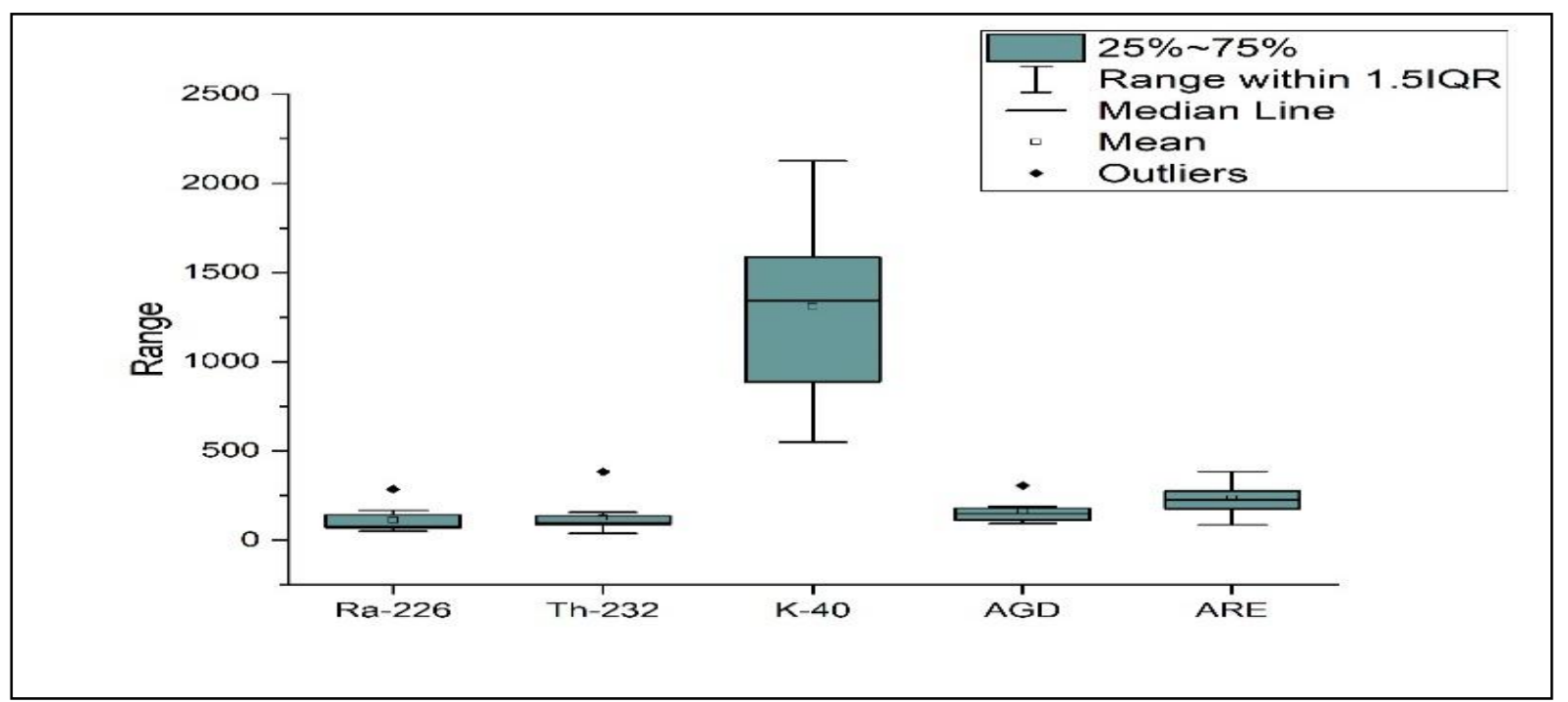

Fig. 6: Box plots of statistical data

Table 2. Statistical values of data

\begin{tabular}{cccccc}
\hline $\begin{array}{c}\text { Study } \\
\text { Area }\end{array}$ & $\begin{array}{c}\text { Ra-226 } \\
(\mathbf{B q} / \mathbf{k g})\end{array}$ & $\begin{array}{c}\text { Th-232 } \\
(\mathbf{B q} / \mathbf{k g})\end{array}$ & $\begin{array}{c}\mathbf{K}-\mathbf{4 0} \\
(\mathbf{B q} / \mathbf{k g})\end{array}$ & $\begin{array}{c}\text { External absorbed } \\
\text { Gamma Dose Raten } \\
(\mathbf{n G y} / \mathbf{h})\end{array}$ & $\begin{array}{c}\text { Average Radium } \\
\text { Equivalent } \\
(\mathbf{B q} / \mathbf{k g})\end{array}$ \\
\hline Max. & $285 \pm 28$ & $384 \pm 53$ & $2126 \pm 176$ & 306.00 & 384.20 \\
Min. & $50 \pm 10$ & $38 \pm 7.37$ & $549 \pm 154$ & 93.00 & 86.00 \\
Averge & 112.78 & 126.46 & 1310.71 & 159.63 & 234.83 \\
S.D. & 72.18 & 96.06 & 675.08 & 64.96 & 85.75 \\
\hline
\end{tabular}

\section{References}

Ahamad T, Singh P, Nautiyal OP, Joshi M, Bourai AA, Rana AS and Singh K (2021) Quantification of $222 \mathrm{Rn} / 220 \mathrm{Rn}$ exhalation rates from soil samples of Champawat region in Kumaun Himalaya, India. Journal of Radioanalytical and Nuclear Chemistry, 1-11.
Al-Khawlany AH, Khan AR and Pathan JM (2018) Review on studies in natural background radiation. Radiation Protection and Environment, 41(4), 215.

Alnour IA, Ibrahim N and Hossain I (2012) Concentrations of $214 \mathrm{~Pb}, 214 \mathrm{Bi}$ in 238 U series and $208 \mathrm{Tl}, 228 \mathrm{Ac}$ in $232 \mathrm{Th}$ series in granite rock in (Kadugli) Sudan. 
Anamika K, Mehra R and Malik P (2020) Assessment of radiological impacts of natural radionuclides and radon exhalation rate measured in the soil samples of Himalayan foothills of Uttarakhand, India. Journal of Radioanalytical and Nuclear Chemistry, 323(1), 263-274.

Ansari K (2018) Crustal deformation and strain analysis in Nepal from GPS timeseries measurement and modeling by ARMA method. International Journal of Earth Sciences, 107(8), 2895-2905.

Bangotra P, Mehra R, Kaur K, Kanse S, Mishra R, Sahoo BK (2015) Estimation of EEC, unattached fraction and equilibrium factor for the assessment of radiological dose using pin-hole cup dosimeters and deposition based progeny sensors. Joun. ofenvir. Radio. 148, 67-73.

Bilham R (2004) Earthquake in India and the Himalaya: Techtonics, geodesy and history. Annals of Geophysics.

Bist VM, Saini KS, K N and Ramola, R C (1999) Relation between soil-gas radon variation and different lithotectonic units, Garhwal Himalaya, India. Applied Radiation and Isotopes, 51(5), 587-592.

Gusain GS, Badoni M, Prasad G, Prasad Y, Ramachandran TV and Ramola RC (2009) Studies of natural radionuclides and dose estimation from soil samples of
Kumaun Himalaya, India. Indian Journal of Physics, 83(8), 1215-1220.

https://en.wikipedia.org/wiki/Geography_of_U ttarakhand

Jonsson G (1988) Indoor 222Rn measurements in Sweden with the solid state nuclear track detector technique. Heal. Phys. 54(3), 271-281, 306.

Kandari T, Aswal S, Prasad M, Bourai AA and Ramola RC (2016) Estimation of annual effective dose from radon concentration along Main Boundary Thrust (MBT) in Garhwal Himalaya. Journal of radiation research and applied sciences, 9(3), 228233.

Kandari T, Prasad M, Pant P, Semwal P, Bourai AA and Ramola RC (2018) Study of radon flux and natural radionuclides (226 Ra, $232 \mathrm{Th}$ and $40 \mathrm{~K}$ ) in the Main Boundary Thrust region of Garhwal Himalaya. Acta Geophysica, 66(5), 12431248.

Kaur I, Gupta A, Singh BP, Sharma S and Kumar A (2019). Assessment of radon and potentially toxic metals in agricultural soils of Punjab, India. Microchemical Journal, 146, 444454.

Krebs RE (2006) The history and use of our earth's chemical elements: a reference guide. Greenwood Publishing Group. 
Kreienbrock L, Kreuzer M, Gerken M, Dingerkus G, Wellmann J, Keller G and Erich Wichmann H (2001) Case-control study on lung cancer and residential radon in western Germany. American Journal of Epidemiology, 153(1), 42-52.

Kumar A, Singh P, Semwal P, Singh K, Prasad M and Ramola RC (2021) Study of primordial radionuclides and radon/thoron exhalation rates in Bageshwar region of Kumaun Himalaya, India. Journal of Radioanalytical and Nuclear Chemistry, 1-7.

Letoureau EG, Kreweski D, Choi NW, Goddard MJ, Mcgregor RG, Zielinski JM, Du J (1994) Case-control study of residential radon and lung cancer in Winnipeg, Manitoba. Canada. Am. J. Epidemiol. 140 (4), 310-322.

Mehra R, Singh S, Singh K and Sonkawade R (2007) $226 \mathrm{Ra}, 232 \mathrm{Th}$ and $40 \mathrm{~K}$ analysis in soil samples from some areas of Malwa region, Punjab, India using gamma ray spectrometry. Environmental monitoring and assessment, 134(1), 333-342.

OECD (Organization for Economic Cooperation and Development). (1979). Exposure to radiation from the natural radioactivity in building material (Paris: Nuclear energy agency, OECD).

Prasad M, Rawat M, Dangwal A, Kandari T, Gusain GS, Mishra R and Ramola RC
(2016) Variability of radon and thoron equilibrium factors in indoor environment of Garhwal Himalaya. Jour. of envir. Rad. 151, 238-243.

Ramola RC, Choubey VM, Prasad Y, Prasad G and Bartarya SK (2006) Variation in radon concentration and terrestrial gamma radiation dose rates in relation to the lithology in southern part of Kumaon Himalaya, India. Radiation Measurements, 41(6), 714-720.

Ramola RC, Gusain GS, Badoni M, Prasad Y, Prasad G and Ramachandran TV (2008) 226Ra, 232Th and 40K contents in soil samples from Garhwal Himalaya, India, and its radiological implications. Journal of Radiological Protection, 28(3), 379.

Ramola RC, Prasad M, Kandari T, Pant P, Bossew P, Mishra R and Tokonami S (2016) Dose estimation derived from the exposure to radon, thoron and their progeny in the environment. Scientific Reports (Nature) 6:31061, DOI: 10.1038/srep31061.

Ramola RC, Singh S and Virk HS (1988) Radon studies over main boundary thrust near Dehradun (India). International Journal of Radiation Applications and Instrumentation. Part D. Nuclear Tracks and Radiation Measurements, 15(1-4), 617-619. 
Ramola RC, Yadav M and Gusain GS (2014) Distribution of natural radionuclide along main central thrust in Garhwal Himalaya. Journal of Radiation Research and Applied Sciences, 7(4), 614-619.

Ramola RC, Yadav M and Gusain GS(2014) Distribution of natural radiation along main central thrust in Garhwal Himalaya. Journal of Radiation Research and Applied Sciences-7. 614-619.

Rautela BS, Yadav M, Bourai AA, Joshi V, Gusain GS and Ramola RC (2012) Study of natural radionuclide and absorbed gamma dose in Ukhimath area of Garhwal Himalaya, India. Radiation protection dosimetry, 152(1-3), 58-61.

Reguigui N (2006) Gamma ray spectrometry. Practical Information.

Semwal P, Singh K, Agarwal TK, Joshi M, Pant P, Kandari T and Ramola RC (2018) Measurement of $222 \mathrm{Rn}$ and $220 \mathrm{Rn}$ exhalation rate from soil samples of Kumaun Hills, India. Acta Geophysica, 66(5), 1203-1211.

UNSCEAR (2000) United Nations Scientific Committee on the Effects of Atomic Radiation. Sources, effects and risk of ionizing radiation, Report to the General Assembly, United Nations, New York.

UNSCEAR (2008) United Nations Scientific Committee on the Effect of Atomic
Radiation. Source and Effects of Ionizing Radiation. Annex - B: Exposures of the Public and Workers from Various Sources of Radiation. Report to the General Assembly. United Nation, New York, vol. I.

Wadiya Valdiya KS (1980) Geology of kumaun lesser Himalaya. Wadia Institute of Himalayan Geology, Dehradun

WHO (2009) World Health Organization. Handbook on Indoor Radon: A Public Health Perspective. WHO Press, Geneva 27, Switzerland.

Yadav M, Prasad M, Joshi V, Gusain G S and Ramola RC (2016) A comparative study of radium content and radon exhalation rate from soil samples using active and passive techniques. Radiation Protection Dosimetry, 171(2), 254-256.

Yadav M, Rawat M, Dangwal A, Prasad M, Gusain GS and Ramola RC (2015) Analysis of natural radionuclides in soil samples of Purola area of Garhwal Himalaya, India. Radiation protection dosimetry, 167(1-3), 215-218.

Yadav M, Rawat M, Dangwal A, Prasad M, Gusain GS and Ramola RC (2014) Levels and effects of natural radionuclides in soil samples of Garhwal Himalaya. Journal of Radioanalytical and Nuclear Chemistry, 302(2), 869-873. 